\title{
WeChat mobile-payment-based smart retail customer experience: an integrated framework
}

\author{
Yinglu Sun $^{1} \cdot$ Wei Xue $e^{2,3} \cdot$ Subir Bandyopadhyay ${ }^{4} \cdot$ Dong Cheng $^{5}$
}

Accepted: 23 October 2021 / Published online: 3 November 2021

(c) The Author(s) 2021

\begin{abstract}
The purpose of this paper is to explore the role of WeChat mobile-payment (m-payment)-based smart technologies in improving the retail customer experience and to develop an integrated framework of the smart retail customer experience including antecedents, consequences, and moderators. Based on the stimulus-organism-response (SOR) paradigm, we investigated the relationships among socio-technical stimuli, the smart retail customer experience, and relationship quality. We also developed hypotheses regarding the moderating role of customer lifetime value (CLV), which is considered an important customer characteristic. The proposed framework was empirically tested based on transaction and survey data of $462 \mathrm{WeChat} \mathrm{m-payment}$ retail customers. The results showed the following. (1) WeChat m-payment-based smart retail technology can enhance the customer experience by improving customer-perceived relationship orientation, employee-customer interaction, and communication effectiveness. (2) CLV has a positive moderating effect on the relationship between socio-technical stimuli and the customer experience. (3) The customer experience has a positive influence on relationship quality in the retail industry. Retail managers should make full use of smart retail technologies to improve the customer experience. In addition, they should emphasize the increase in CLV, as this increase enhances the positive relationship between socio-technical stimuli and the customer experience, making customer experience management more efficient.
\end{abstract}

Keywords Retail customer experience $\cdot$ Smart retail technologies $\cdot$ WeChat mobile payment $\cdot$ Social-technical stimuli . Customer lifetime value (CLV)

\section{Introduction}

The customer experience is a growing priority for both practice and research. An increasing number of retail firms view the customer experience as a strategic differentiator that can give them sustainable competitive advantages. Customers make purchase decisions based on their experiences.

Dong Cheng

chengdong@rmbs.ruc.edu.cn

1 National Academy of Innovation Strategy, CAST, Beijing 100863, China

2 Center for Applied Statistics of Renmin, University of China, Beijing 100872, China

3 School of Statistics, Renmin University of China, Beijing 100872, China

4 School of Business \& Economics, Indiana University Northwest, Gary, IN 46408, USA

5 Business School, Renmin University of China, Beijing 100872, China
According to a Forbes survey, $86 \%$ of customers will pay more for a better customer experience [1]. However, significant disparities exist between what firms believe they offer their customers and what customers actually experience during their customer journey [2]. Improving the customer experience is a challenge for practitioners and academic researchers [3].

The concept of "customer experience" was first introduced in 1982 by Hobrook and Hirschman [4], emphasizing "experiential perspectives of consumption." To date, researchers have conducted exploratory studies on the concept and dimensions [3, 5], the measurement [6, 7], the antecedents and consequences [8-10], and the moderators [11] of the customer experience. In particular, the contemporary retailing landscape triggered by smart retail technologies (SRTs) has posed new challenges to customer experience management (CEM). The concept of smart retail emerged from the smart city phenomenon. "Smartness" refers to enhancing processes and efficiency on the retailer side and improving satisfaction and utility on the consumer side [12, 
13]. Over the past few years, an increasing number of traditional retail stores have incorporated smart retail technologies into their day-to-day practice and created smart partnerships between retailers and consumers [13]. The various smart retail technologies include touch screens, interactive displays, nearfield communication, tablets, and QR codes, among others. A recent report predicted that smart retail technology's global market size would grow by approximately $20 \%$ to reach $\$ 35.64$ billion by 2020 [14]. With the rapid development of smart technologies, it is worth exploring how these technologies contribute to the retail customer experience. Although researchers believe that these cuttingedge technologies can improve the customer experience [15], empirical evidence supporting this belief is scarce. Few studies have explored the effect of smart technologies on retail customer experience. To address this research gap, the purpose of this paper is to examine the role of smart technologies in improving retail customer experience and to develop an integrated framework of smart retail customer experience that includes antecedents, consequences, and moderators.

This research focuses on a broadly adopted smart retail technology in China, i.e., the WeChat mobile-payment (m-payment)-based smart retail system. WeChat Pay is one of China's most popular payment methods, providing a smart and efficient payment solution for both consumers and merchants. It is used by hundreds of millions of consumers every day, especially by shops in brick-and-mortar stores. In addition, WeChat Pay empowers retailers to connect with consumers before, during, and after sales through innovative marketing platforms in the WeChat ecosystem. For example, brick-and-mortar retailers can push customized instant messages, including advertising, coupons, and promotion information, soon after payment. WeChat m-payment offers comprehensive support to help brick-and-mortar stores build a smart retail system. Therefore, in this paper, we propose a smart retail customer experience framework based on WeChat m-payment and empirically test it based on a dataset of 462 consumers shopping in a large brick-and-mortar Chinese retailer.

In the next sections, we review the theoretical background, lay out the conceptual framework, develop the research hypotheses, describe the methods and discuss the results and implications of our research for theory and practice.

\section{Theoretical background}

\subsection{Technology and customer experience}

With the rapid development of smart retailing, the role of technology has received increasing research attention. From self-service technologies (SSTs) [8] to virtual, augmented, and mixed reality technologies [15], researchers have highlighted the importance of technology for the customer experience. For example, Flavián et al. [15] proposed that technology might support or empower the customer experience and produce new experiences along the customer journey. Thomas [16] asserted that the advent of new digital technologies is the catalyst for personalized experiences. Parise et al. [17] also contended that digital technology can transform the customer experience. Rodríguez et al. [18] believed that technology-based resources can contribute to supporting the customer experience during the shopping process.

This research domain can be divided into three frequent themes, i.e., online customer platforms, SSTs, and emerging digital technologies [19]. Online servicescapes and platforms have created opportunities for a variety of customerorganization interactions [20]. For example, researchers have studied the quality of website services and mobile services in driving effective customer experiences [21, 22]. SSTs expand customer interaction with organizations and allow customers to personalize their experiences [8]. Emerging digital technologies play an increasingly important role in improving the customer experience. An increasing number of studies have focused on customer experiences arising from the use of emerging technologies. For example, Chylinksi et al. [23] conceptualized augmented reality marketing and believed that it can improve customer experiences and decision making. Dacko [24] discussed how mobile augmented reality apps contribute to smart retail settings and offer users experiential value. Flavián et al. [15] described the impact of virtual, augmented and mixed reality technologies on customer experience. Dieck and Han [25] also looked at the role of immersive technologies such as augmented and virtual reality as part of the CEM (CEM) process. Hoyer et al. [26] believed that new technologies such as the Internet of Things, augmented reality, virtual reality, mixed reality, virtual assistants, chatbots, and robots are dramatically transforming the customer experience.

Given the rapid development of new retail technologies, understanding their role in the customer experience is essential to both researchers and practitioners. Although there is a growing connection between technology and customer experience research, the current literature is rather fragmented and few studies have explored the effect of smart technologies on the retail customer experience. An integrated framework including antecedents, consequences, and moderators is needed to understand the customer experience in today's technological environment.

\subsection{Mobile payment and customer experience}

Thanks to the widespread use of mobile phones, m-payment is one of the most popular payment tools in society today. M-payment may be defined as transactions in which mobile 
devices, such as cell phones, tablets, or PDAs, are used to initiate, authorize and confirm an exchange of financial value in return for goods or services [27]; transfers of funds in return for goods or services in which a mobile device is functionally involved in executing and confirming payment [28]; or a solution utilizing mobile devices to perform transactions [29]. In essence, m-payment is cashless payment made for a product or service using mobile devices such as smartphones or tablets.

As a new retail technology that has emerged in recent years, $\mathrm{m}$-payment has revolutionized the way people pay in brick-and-mortar stores. Replacing cash and credit cards, $\mathrm{m}$-payment offers a more convenient, flexible, and timesaving way of paying. Researchers believe that because $\mathrm{m}$-payment allows users to complete their payments anytime and anywhere and in a safer, faster, and more convenient manner [30-32], it has a positive impact on the retail shopping experience. Cox and Sanchez [33] believed that mobile wallets can transform the customer experience. According to Tayor [27], m-payment has the potential to redefine brickand-mortar stores by making checkouts simpler and faster.

With the rapid development of mobile technologies, $\mathrm{m}$-payment is now more than just payment; it has become an ecosystem or platform that combines payment, marketing (i.e., offers and coupons), loyalty, and money management [33]. Taking China as an example, the country's two leading m-payment service players, Alibaba's Alipay and Tencent's WeChat Pay, have built ecosystems around their m-payment tools. These ecosystems can provide comprehensive support to help stores become "smarter". In this study, we focus on the WeChat m-payment-based smart retail system and investigate how this emgering retail technology may affect the customer experience.

\subsection{Moderators of customer experience}

Moderators may play a dominant role in the creation of the customer experience. However, few researchers have investigated this topic [34]. According to the conceptual framework proposed by Verhoef et al. [8], customer experience moderators can include situation moderators (such as stores' type and location, culture, economic climate, season, and competition/entrance) and consumer moderators (such as consumers' shopping goals, sociodemographics, and attitudes). Jain et al. [10] summarized customer experience moderators into three categories: customers, including demographic, psychographic, personal, social, and cultural characteristics; macroenvironment, including economics and technology; and situational, including competition, type of store, product/service category, location, and purchase timing. In a review by Varshneya et al. [34], possible customer experience moderators included income, age, gender, culture, mood, sensitivity, perceived risk, locus of control, and familiarity. Esbjerg et al. [11] proposed that shopping motives (task-oriented vs. recreational) may moderate the relationship between the store environment and shopping trip experiences. Le and Nguyen-Le [35] empirically tested the moderating role of internet usage in the relationship between channel integration quality and the customer experience.

The limited literature on moderators shows that customer characteristics play an indispensable role in customer experience research. For example, sociodemographic characteristics such as age, gender, and income and psychographic characteristics such as mood, attitude, shopping motives, perceived risk, locus of control, and familiarity are considered critical moderators of the customer experience [10, 11, 34]. Beyond these sociodemographic and psychographic characteristics, the moderating effect of customer trading behavior characteristics remains to be verified.

An important variable reflecting customer trading behavior characteristics is customer lifetime value (CLV), which refers to the net present value of profit that a customer can bring to a firm during the customer's lifetime of transactions with the firm [36]. Researchers believe that CLV works as the basis for firms to segment their customers and allocate marketing resources [37]. Segmenting customers based on their lifetime value and designing corresponding marketing schemes can bring more profits to retailers than segmenting customers based on sociodemographic characteristics [36, 38]. In this paper, we investigate the moderation effect of CLV.

\section{Conceptual framework and hypothesis development}

In this section, we propose an integrated framework of smart retail customer experience in the new technology environment. Our framework is based on the stimulus-organismresponse (SOR) model. Proposed by Mehrabian and Russell in 1974 [39], the SOR model proposes that environmental stimuli (S) affect the internal emotional states of an individual $(\mathrm{O})$, which then influence his or her approach or avoidance behaviors (R). Donovan and Rossiter [40] first introduced the SOR model in retail settings, testing two central emotional states-pleasure and arousal-as significant mediators between store atmosphere and intended shopping behavior.

In recent years, the SOR model has been adapted by researchers to study the customer experience [41-45], which Lemon and Verhoef [3] defined as a "Customer's cognitive, emotional, behavioral, sensorial and social response to a firm's offerings during the customer's entire purchase journey". Klaus and Maklan [6] believed that the customer experience is "the metal perception of interaction," which in turn drives a set of benefits, emotions, judgments, and intentions. 


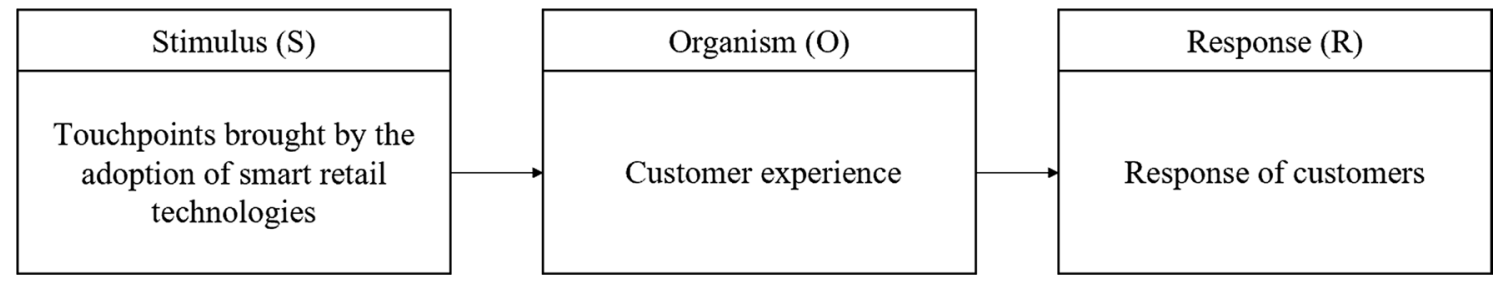

Fig. 1 Conceptual framework based on SOR model

According to Verhoef et al. [8], the customer experience "involves the customer's cognitive, affective, emotional, social and physical responses to the retailer". Therefore, the customer experience is essentially the internal state of an individual $(\mathrm{O})$. In this context, the organism's environmental stimuli (S) are touchpoints that customers interact with during the customer journey, and response (R) refers to customer behaviors, such as repurchase intention, brand engagement, and word of mouth (WoM). In our research, the touchpoints brought by the adoption of smart retail technologies work as stimuli $(\mathrm{S})$ in the customer experience $(\mathrm{O})$, and the experience brought by smart retail technologies further affects the response of customers (R) (see Fig. 1).

\subsection{Antecedents of smart retail customer experience: STS as an environmental stimulus}

Most research on the antecedents of the customer experience is based on the store attribute perspective, emphasizing the influence of store attributes such as retail assortment, accessibility, layout/scale, atmosphere, price, location and promotion on the retail customer experience [9, 46, 47]. In this study, we explore the antecedents of the smart retail customer experience in the context of new technologies from a new research perspective, i.e., a socio-technical system (STS) perspective, to help us understand the role of smart technologies and their working mechanism in the retail customer experience.

According to the STS perspective, a firm consists of two interacting systems, i.e., the social system and the technical system. The social system is concerned with people, and the technological system is concerned with processes, tasks, and technology [48, 49]. As an STS, a retailer provides customer touchpoints in terms of social and technical aspects during the customer journey. These social-technical touchpoints communicate something positive or negative about the firm. Customers' interaction with these touchpoints can influence their customer experience [10]. For example, Smith et al. [41] investigated the interplay between technical and social systems within an organization that potentially affect the customer service experience.

Leavitt [50] proposed the diamond model of STS that includes four essential interacting components within an
STS: technology, structure, people, and tasks (see Fig. 2). Our paper mainly focuses on the influence of technology on the other three components, i.e., structure, people, and tasks, to investigate the working mechanism of the retail customer experience. We propose that smart retail technology can affect a firm's structure, people, and tasks. More specifically, we focus on the retailer's relationship orientation as the touchpoint of the structure dimension, employee-customer interaction as the touchpoint of the people dimension, and communication effectiveness as the task dimension.

\subsubsection{Technology adoption and relationship orientation}

Relationship orientation is defined as "an organization engaged in proactively creating, developing and maintaining committed, interactive and profitable exchanges with selected customers over time" [51]. Relationship marketing has become a dominant strategy for retail firms. Instead of focusing on one-off transactions, retailers are now devoting more effort to maintaining and enhancing long-term customer relationships. First, the relationship-oriented marketing strategy should be customer-centered. To establish and maintain long-term customer relationships, retailers should fully understand customer needs, provide personalized services and personal care based on these needs [52] and finally establish emotional connections and long-term relationships with customers. Second, the relationship-oriented marketing strategy should be based on interaction. Interaction is the premise of establishing a relationship between retailers and customers [53], and the quality of interaction determines the quality of relationship marketing [54].

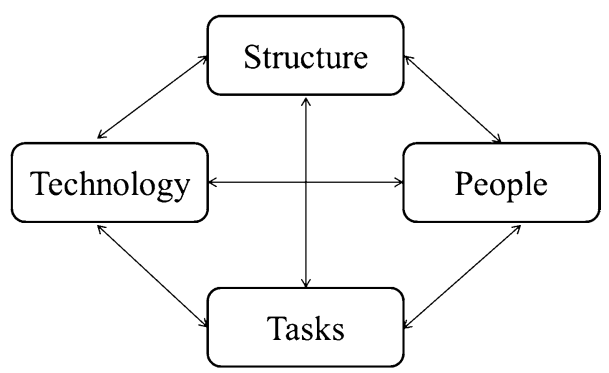

Fig. 2 Leavitt's Diamond Model of STS [50] 
Adopting the WeChat m-payment-based smart retail system helps firms capture real-time data on their customers and allows retailers to push customized instant messages, such as coupons or promotion information, according to their customers' shopping behavior. This empowers firms with new capabilities to increase the relationship orientation perceived by their customers. More specifically, the WeChat m-payment-based smart retail system makes it possible to capture, integrate and analyze massive customer behavior data, such as trading and commenting data. By collecting massive customer data, retailers can learn more about customers' needs and preferences through data mining to truly be customer-centric. In addition, the WeChat m-payment-based smart retail system gives retailers the ability to interact with customers in real time, which makes the interaction between customers and retailers easier and more convenient. When a customer can interact directly with a firm, it is easier for the customer to establish an emotional connection with the firm, and both parties are more inclined to understand and cooperate with each other; this contributes to relationship orientation [55]. Therefore, we hypothesize the following:

H1 Technology adoption has a positive effect on relationship orientation.

\subsubsection{Technology adoption and employee-customer interaction}

Employees are the most important social elements in an organization. According to Larivière et al. [56], employees are enablers, innovators, coordinators, and differentiators in "service encounter 2.0". The core of retail service lies in the interaction between employees and customers [57]. The application of emerging technologies in an organization can enhance employees' work skills and affect their attitudes and behaviors by giving them advanced tools and equipment and helping them think, analyze and take actions. Therefore, emerging technologies can reshape the role of employees in the process of interaction with customers.

Taking advantage of the WeChat m-payment-based smart retail system, frontline staff can offer individual customers personal attention and services. On the one hand, this system can collect massive purchase and payment data on customers. Analyzing these data gives frontline staff a better understanding of customers. On the other hand, employees can recognize an individual customer according to his or her payment ID, offer personalized services during the buying process and even continue to interact with the customer after his or her purchase with the help of the WeChat ecosystem. Therefore, we posit the following:
H2 Technology adoption has a positive effect on employeecustomer interaction.

\subsubsection{Technology adoption and communication effectiveness}

Marketing is the primary task of retailers, and the essence of marketing is to communicate with customers through effective media. With the development of relationship marketing, marketing communication has gradually changed from product-driven mass market communication to customeroriented integrated marketing communication with stronger pertinence and interactivity [58]. SRTs can change the way retailers communicate and improve communication effectiveness in the following ways. First, SRTs can increase retailers' customer insight, which refers to the understanding of customer motivation and behavior. Smart retail technologies allow retailers to continuously obtain massive customer data and information and transform the original data into customer insights through dynamic analysis systems. Second, SRTs can enhance retailers' ability to formulate communication plans. With the help of emerging technologies, retailers can develop communication plans based on customer insight, better measure the effects of marketing communication, and adjust their communication plans according to these effects. Last, smart retail technologies allow retailers to use different communication tools and different platforms for different customer segments, thus improving the effectiveness of retailers' marketing communication. The WeChat m-payment-based smart retail system can collect massive customer data according to customers' payment ID, thus facilitating customer data collection and information management. Rich knowledge of customers enables retailers to communicate the "right" information to the "right" people at any time or any place, further enhancing personalized communication and promotion. Therefore, we hypothesize the following:

H3 Technology adoption has a positive effect on communication effectiveness.

\subsubsection{Technology adoption and retail customer experience}

Smart technology shapes the new retail environment and has the potential to improve the customer experience. Researchers have emphasized the importance of technology for the customer experience. For example, Foroudi et al. [59] asserted that the customer experience depends on firms' technical innovation capability. Rodríguez et al. [18] believed that technology use represents core elements for developing a satisfying customer experience. The authors proposed a model called Shopping Experience Design, which emphasizes the role of technology in delivering a 
superior customer experience. Flavián et al. [15] studied the effect of virtual-reality, augmented-reality, and mixedreality technologies on customer experience. They proposed that these technologies might not only enhance the customer experience but also produce new experiences.

SRTs can help improve the customer experience in four different ways. First, emerging technologies can provide customers with more convenient and fast shopping services. Second, these technologies can provide customers with personalized shopping experiences. Third, these technologies can enhance the interactive experience of customers during shopping. Last, these technologies can not only improve the customer experience but also create an unprecedented, new experience for customers. This paper focuses on the WeChat m-payment -based smart retail system and analyzes the relationship between technology adoption and the customer experience. WeChat m-payment is cash free, and it is a faster, safer, and more convenient way for customers to pay for goods or services at brick-and-mortar stores. In addition, the WeChat m-payment-based smart retail system enables retailers to acquire, store, and analyze customer big data, improves interaction, and presents opportunities for more personalized high-quality services, thus improving the customer experience. We therefore hypothesize the following:

H4 Technology adoption has a positive effect on the retail customer experience.

\subsubsection{Relationship orientation and retail customer experience}

Relationship orientation reflects an organization's engagement in developing and maintaining a long-term relationship with customers. Pressey and Mathews [60] proposed seven dimensions central to relationship marketing in a retail context: a high level of trust, a high level of commitment, a long relationship, open communication channels, having customers' best interest at heart, a commitment to quality, and an attempt to retain customers. All of these efforts made by firms help improve the customer experience. More specifically, relationship orientation is customer-centric. It involves understanding customer needs and organizing business activities based on these needs [61]. Relationship orientation can be reflected in all aspects of the customer's shopping process, such as providing personalized products and services according to customers' needs, providing aftersales service, treating customers sincerely, and establishing emotional connections with customers. These aspects undoubtedly have a positive role in improving the customer experience. Therefore, we hypothesize the following:

H5 Relationship orientation has a positive effect on the retail customer experience.

\subsubsection{Employee-customer interaction and retail customer experience}

Several researchers have emphasized employee-customer interaction as a critical driver of the customer experience. Through qualitative research, Stein and Ramaseshan [62] observed that employee-customer interaction is an important customer experience touchpoint. Experienced and knowledgeable employees, personalized service, and friendly greetings can contribute to a positive customer experience. According to Kim and Choi [63], the perceived quality of employee-customer interaction is a vital determinant of the customer experience. Srivastava and Kaul [64] believed that social interaction between customers and employees positively and directly affects the customer experience. In addition to in-store face-to-face encounters, other retail channel interactions, such as those on telephone, email, and online forums, can also influence the customer experience [62]. For example, McLean and Osei-Frimpong [65] studied the effect of a web-based service representative on the customer experience. Enhanced interactivity between employees and customers enables customers to obtain more relevant information, better understand products and services, and obtain more feedback, support and help during the shopping process; this improves the customer experience. Thus, we hypothesize the following:

H6 Employee-customer interaction has a positive effect on the retail customer experience.

\subsubsection{Communication effectiveness and retail customer experience}

Marketing communication is a crucial touchpoint during the customer journey. According to Brakus et al. [66], brand experience is the feeling, emotion, cognition and behavior that emerge in reaction to brand-related stimuli, and marketing communication is one of the important stimuli related to a brand. Although marketing communication is generally considered to influence the customer experience in the search and evaluation stage before purchase, Stein and Ramaseshan [62] found through semistructured interviews that marketing communication also plays an important role in the purchase and post-purchase stages. For example, one interviewee said that receiving purchase confirmation and delivery notification emails from retailers after a purchase brings peace of mind and self-confidence and optimizes the shopping experience. The influence of marketing communication on the customer experience runs through customers' entire shopping journey. In addition, according to [62], advertisements and promotional or informative messages are basic communitive elements. Researchers have mainly focused on promotional information as stimuli in the retail 
customer experience [9], while studies on the other two elements are rather scarce. The influence of retailers' marketing communication on the customer experience is worth exploring. Therefore, from the perspective of retailers' communication effectiveness, we propose the following hypothesis:

H7 Communication effectiveness has a positive effect on the retail customer experience.

\subsubsection{Mediating effects of relationship orientation, employee-customer interaction, and communication effectiveness}

Smart technology can empower a retailer with new capabilities to optimize its management and structure [12, 67], enhance employee competence [68], and improve its communication [69]. Specifically, the WeChat m-payment-based smart retail system can help retailers capture a massive amount of customer data, push customized instant messages, offer personalized services and interaction, and communicate the "right" information to the "right" people. All of these capabilities empowered by the WeChat m-paymentbased smart retail system help improve relationship orientation, employee-customer interaction, and communication effectiveness. As social-technical touchpoints, relationship orientation, employee-customer interaction, and communication effectiveness can further influence the customer experience $[62,70]$. Therefore, we hypothesize the following:

H8 Relationship orientation mediates the relationship between technology adoption and the retail customer experience.

H9 Employee-customer interaction mediates the relationship between technology adoption and the retail customer experience.

H10 Communication effectiveness mediates the relationship between technology adoption and the retail customer experience.

\subsection{Consequences of smart retail customer experience: relationship quality as a response to customer experience}

Researchers have explored the influence of the customer experience on customer attitudes and behaviors, such as satisfaction, loyalty, WoM, shopping frequency, and repurchase intentions $[9,10,71]$. Few studies have empirically tested the influence of the customer experience on the relationship quality between retailers and customers. Relationship quality is defined by Henning-Thuran and Klee [72] as "the degree of appropriateness of a relationship to fulfill the needs of the customer associated with the relationship." It is a key concept in relationship marketing and serves as an indicator of the strength of customers' long-term relationship with a service provider [73]. Relationship quality consists of two basic dimensions, i.e., trust and satisfaction [73]. Trust refers to the level of customer confidence in a firm's integrity and reliability [74]. Satisfaction is defined as "the degree to which interactions between the customer and service provider meet customer expectations" [75]. Researchers have found that customer experience significantly influences trust $[74,76]$ and satisfaction $[17,45]$. In addition, some studies have directly focused on the effect of the customer experience on relationship quality. For example, Rajaobelina [77] examined the impact of the customer experience on relationship quality in travel agencies. Jin et al. [75] studied the influence of experiential value on relationship quality in a full-service restaurant setting. However, to the best of our knowledge, there is no empirical study investigating the impact of the customer experience on relationship quality in the retail industry. Therefore, we propose the following hypothesis:

H11 The customer experience has a positive effect on the relationship quality between customers and a retailer.

\subsection{Moderators of smart retail customer experience: customer lifetime value}

Exploring moderators helps scholars and practitioners understand different customers' experiences in different situations. Very little empirical research has examined customer experience moderators, although prior studies have identified customer moderators such as demographic, psychographic, and personal characteristics $[8,10]$. In this paper, we focus on the characteristics of customer trading behavior. We propose the moderating effect of an important variable reflecting the trading behaviors of retail customers, i.e., CLV, testing whether the effects of STS touchpoints on the customer experience vary with the level of CLV.

CLV reflects customers' trading behaviors. Customers with a higher lifetime value are more inclined to buy more products with a higher value from a retailer for a long time in the future. In the human memory, a memory of any event fades over time. Since customers with a higher lifetime value purchase more often from a retailer, their positive perceptions and evaluations of the retailer are reinforced as their number of purchases increases, while their perceptions of unpleasant service interactions fade and become more neutral over time [78]. Prior studies have found that behavioral loyalty may affect customers' perceptual responses, such as their perception of service quality [79], their perceived importance of brand attributes [80, 81], and their satisfaction [82]. For example, Bird et al. [83] found that loyal 
STS touchpoint as environment stimuli (S)

Organism (O)

Response (R)

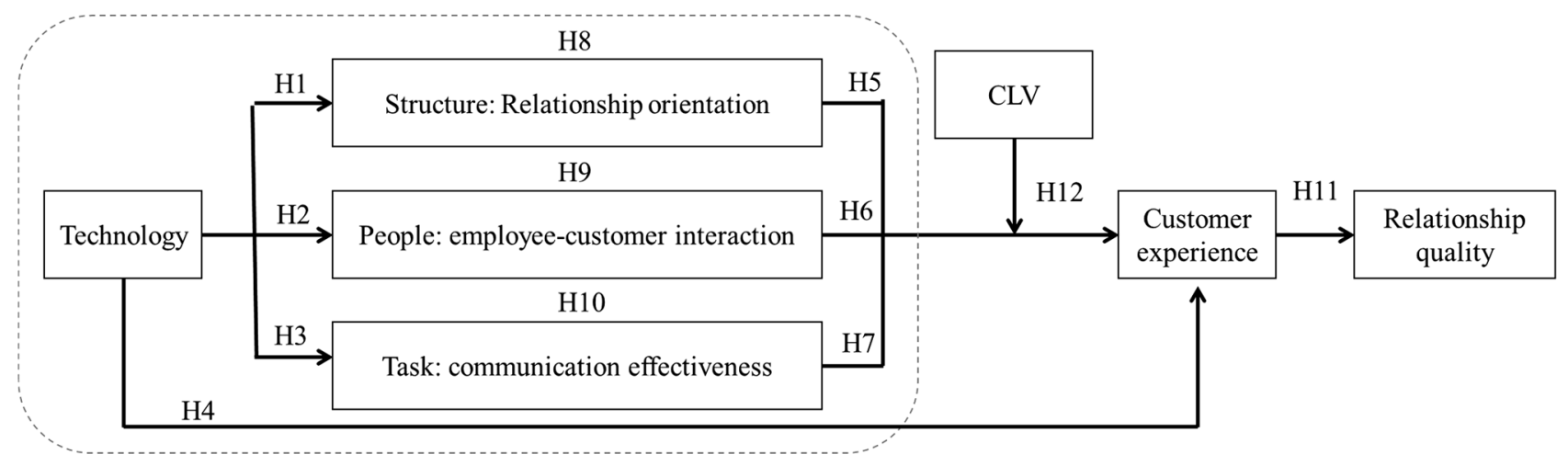

Fig. 3 Conceptual framework: an integrated framework of smart retail customer experience

customers usually have more positive brand image perceptions than disloyal customers in the FMCG category. In the B2B category, loyal customers are also found to evaluate their suppliers more positively [84]. Since CLV reflects the profits a retailer can generate from a customer during the customer's entire lifetime of transactions with the retailer, customers with a higher level of CLV usually have built a longer relationship with the retailer, which means they are loyal customers. Therefore, the evaluation and perception of customers with a higher level of CLV to a service or product provider are more favorable than those of customers with a lower level of CLV. In addition, customers with a higher lifetime value are more familiar with the retailer than customers with a lower lifetime value who buy less from the retailer. According to [82], a higher level of familiarity improves customers' positive perceptions toward a retailer. Therefore, when CLV increases, customer perceptions and evaluations of STS touchpoints enabled by smart retail technologies will become more positive. Therefore, we hypothesize the following:

H12 CLV moderates the relationships between the customer experience and (a) relationship orientation, (b) employeecustomer interaction, and (c) communication effectiveness such that these relationships are more positive when CLV increases.

The research framework is presented in Fig. 3.

\section{Research method}

\subsection{Sample and data collection}

Our proposed theoretical framework includes both customers' attitudinal variables and their behavioral variables. Thanks to the rapid development of WeChat m-payment, we achieved data collection and data matching by accurately pushing the questionnaire to target customers based on their WeChat payment ID with the help of an m-payment aggregator. Specifically, we followed the steps below. First, we targeted customers who were following the retailer's WeChat official account. The WeChat official account is the channel of communication within the WeChat ecosystem. It provides firms and organizations with business services including sending followers messages, vouchers, and surveys. ${ }^{1}$ Second, we targeted followers who had a purchase history dating back to August 2015. Third, the survey was sent automatically to customers after making a payment using WeChat Pay. More specifically, when potential respondents made a purchase and paid using WeChat Pay in any retailer's branch store, they received a push notification of the survey on his or her friend chat list immediately after payment. Respondents were told that they would receive a $50 \mathrm{RMB}$ shopping coupon from the retailer after they filled out the questionnaire. According to our pretest before the data collection process, most consumers agreed to participate when we raised the incentive coupon amount to $50 \mathrm{RMB}$.. In addition, as WeChat Pay is used by $93 \%$ of consumers in offline purchases in tier 1 and 2 cities in China, ${ }^{2}$ our sample selection was random and no sample selection issues affected the reliability of our results. The data collection process lasted one week. In total, 462 respondents completed the survey.

According to customers' unique WeChat payment IDs, the historical transaction data from August 18, 2015, to May 7,2019 , of these 462 respondents with the retailer could be tracked and extracted through the payment database of the m-payment aggregator. Finally, we merged the survey data and the transaction data of the 462 respondents and obtained

\footnotetext{
${ }^{1}$ For more information about WeChat and WeChat official accounts, please refer to http://www.wechat-help.com/official_account/.

2 https://99firms.com/blog/wechat-statistics/.
} 
Table 1 Operationalization of constructs

\begin{tabular}{|c|c|c|}
\hline Construct & Operational definition & Measurement \\
\hline Technology adoption & $\begin{array}{l}\text { Customers' perceived congruence between their } \\
\text { expectation of the retailer's smart technology adop- } \\
\text { tion and its actual performance }\end{array}$ & $\begin{array}{l}\text { Multiple-item measurement adapted from Bhattacher- } \\
\text { jee's [86] confirmation of IS expectations scale }\end{array}$ \\
\hline Relationship orientation & $\begin{array}{l}\text { Customers' perception of the retailer's relationship } \\
\text { orientation }\end{array}$ & $\begin{array}{l}\text { Multiple-item measurement adapted from Aurier \& } \\
\text { Séré de Lanauze's [87] perceived brand relationship } \\
\text { orientation scale }\end{array}$ \\
\hline Employee-customer interaction & $\begin{array}{l}\text { Customers' perception of their interactions with } \\
\text { employees of the retailer }\end{array}$ & $\begin{array}{l}\text { Multiple-item measurement adapted from Terblanche's } \\
\text { [7] interaction with staff scale }\end{array}$ \\
\hline Communication effectiveness & $\begin{array}{l}\text { Customers' perception of the communication effec- } \\
\text { tiveness of the retailer }\end{array}$ & $\begin{array}{l}\text { Multiple-item measurement adapted from Sharma \& } \\
\text { Patterson's [88] communication effectiveness scale }\end{array}$ \\
\hline Customer experience & $\begin{array}{l}\text { Customers' perception of their shopping experience } \\
\text { with the retailer }\end{array}$ & $\begin{array}{l}\text { Multiple-item measurement adapted from Bagdare \& } \\
\text { Jain's [89] retail customer experience scale }\end{array}$ \\
\hline Relationship quality & $\begin{array}{l}\text { Customer's evaluation of their long-term relationship } \\
\text { quality with the retailer }\end{array}$ & $\begin{array}{l}\text { Multiple-item measurement adapted from Rajaobelina's } \\
\text { [77] relationship quality scale }\end{array}$ \\
\hline CLV & Customers' contribution to profit in the next 20 weeks & $\begin{array}{l}\text { Single-item measurement predicting the frequency } \\
\text { (Pareto/GGG) and monetary value (gamma-gamma } \\
\text { distribution) of each customer's future purchase }\end{array}$ \\
\hline
\end{tabular}

a dataset comprising both their attitudinal and behavioral data. The majority of the consumers (approximately 70\%) were women, $82 \%$ of the consumers had made more than ten purchases, and the accumulated purchase value at the retailer ranged from $12 \mathrm{RMB}$ to as much as 45,248 RMB since January 2017.

\subsection{Measurement}

All constructs except CLV were measured using five-point Likert scales anchored by "strongly disagree" and "strongly agree." The scales were drawn from measures previously validated in related research and were reworded to adapt them specifically to retailing. CLV was operationalized using a single-item measure. This concept is treated as observable characteristics such as age, sales, and profits; thus, a single-item measure is appropriate [85]. Table 1 provides operational definitions and sources for these constructs. "Appendix 1" contains the scale items, loadings, and reliability statistics.

Technology adoption was measured using three reflective items adapted from Bhattacherjee's confirmation (of technology expectations) scale [86]. This scale was originally designed to measure the confirmation of expectations from information system (IS) adoption, i.e., users' perception of the congruence between their expectations of IS adoption and actual IS performance. We used this scale to capture the congruence between respondents' expectation of the retailer's smart technology adoption, particularly the WeChat m-payment-based smart retail system, and its actual performance, reflecting the retailer's technology adoption level as perceived by the respondents. Relationship orientation items were adapted from Aurier and Séré de Lanauze's perceived brand relationship orientation measures [87]. Employeecustomer interaction was measured using the reflective scale developed by [7]. The three reflective items of communication effectiveness were adapted from Sharma and Patterson's communication effective scale initially designed for professional services [88]. Customer experience was measured using reflective items adapted from Bagdare and Jain's retail customer experience measures [89]. The scale captured four retail customer experience dimensions, i.e., mood, joy, leisure, and distinctiveness. The items measuring relationship quality were adapted from Rajaobelina's relationship quality scale, which was also reflective and emphasized two basic dimensions: trust and satisfaction [77].

As a behavioral variable, CLV is measured by customers' transaction data. The basic CLV model is described as $\mathrm{CLV}=\sum_{i=1}^{n} \frac{\left(R_{i}-C_{i}\right)}{(1+d)^{i-0.5}}$, where $i$ represents the period of cash flow from a customer transaction; $R_{i}$ is the revenue from the customer in period $i ; C_{i}$ is the total cost of generating revenue in period $i ; n$ is the total number of periods of the projected life of the customer under consideration; and $d$ is the discount rate [90]. Researchers have proposed various models to measure CLV. Some models have focused on measuring CLV components, such as purchase frequency and contribution margin, separately and then combined them to predict CLV. In contrast, some studies have proposed simultaneously modeling related elements to achieve more accurate results [91]. In this paper, we measure purchase frequency (F) based on the Pareto/GGG model [92] and measure monetary value (M) using the gamma-gamma distribution [93]. Assuming that purchases $\mathrm{F}$ and $\mathrm{M}$ are independent of each other, CLV can be obtained by the product of the two submodels without considering the customer 
Table 2 Correlations and discriminant validity

\begin{tabular}{llllllll}
\hline & 1 & 2 & 3 & 4 & 5 & 6 \\
\hline 1 & Technology adoption & $\mathbf{0 . 9 2 1 0}$ & & & & & \\
2 & Relationship orientation & 0.6913 & $\mathbf{0 . 9 3 4 0}$ & & & & \\
3 & Employee-customer interaction & 0.7269 & 0.7652 & $\mathbf{0 . 9 1 0 8}$ & & & \\
4 & Communication effectiveness & 0.7248 & 0.7614 & 0.8214 & $\mathbf{0 . 8 9 4 4}$ & & \\
5 & Customer experience & 0.6592 & 0.7344 & 0.7974 & 0.8136 & $\mathbf{0 . 9 1 0 1}$ & \\
6 & Relationship quality & 0.7044 & 0.7339 & 0.8265 & 0.8185 & 0.8196 & $\mathbf{0 . 9 1 9 6}$ \\
\hline
\end{tabular}

Square-root of AVE on the diagonal in bold; correlations below the diagonal acquisition cost or discount rate [94]. "Appendix 2" shows the CLV of some customers.

\subsection{Data analysis}

To test our hypotheses, we applied PLS-SEM to create the underlying path model and estimate its relationships using SmartPLS 3.2. PLS-SEM is a useful tool to develop and test theory in management research. We chose to use PLSSEM over covariance-based methodologies for the following reasons. (1) Our number of observations was relatively small. PLS-SEM works particularly well for models with a large number of constructs but a small sample size [85]. The guideline for the minimum sample size requirement for PLSSEM follows the "ten times rule" [95], which means that the minimum sample size should be ten times the most significant number of arrowheads directed at a latent variable anywhere in the PLS path model. According to the sampling rule of thumb, we could safely conclude that our sample size of 462 was adequate for this research. (2) Our model contains both reflective constructs and a single-item construct. PLS-SEM can easily incorporate reflective and formative measurement models, as well as single-item constructs, with no identification problems, which made PLS-SEM an appropriate tool for our study. (3) PLS-SEM has greater statistical power, meaning that PLS-SEM is "more likely to render a specific relationship significant when it is in fact significant in the population" [85].

\section{Results}

\subsection{Measurement model evaluation}

Before testing the structural model, we first evaluated the reliability and validity of the scales. The values are reported in "Appendix 1". Reliability was assessed by examining indicator reliability and construct reliability. All item loadings were significant $(\mathrm{p}<0.001)$ and greater than 0.7 , ensuring indicator reliability. Construct reliability was assessed by examining composite reliability (CR), and all constructs exhibited satisfactory internal consistency reliability, with all CR values above the recommended threshold of 0.7.

We used average variance extracted (AVE) to establish convergent validity, and all constructs had an AVE value higher than the recommended threshold of 0.5. Discriminant validity was tested according to the Fornell-Larcker criterion, which compares the square root of AVE values with latent variable correlations. Discriminant validity is established when the square root of the AVE of each construct is greater than its highest correlation with other constructs [96]. The results in Table 2 show no problems concerning discriminant validity.

\subsection{Structural model evaluation}

After establishing confidence in the reliability and validity of the measurement, we examined the structural model.

First, we assessed the structural model for collinearity issues. A variance inflation factor (VIF) above 5.0 is usually considered to indicate collinearity [85]. Table 3 shows that there are no collinearity problems in the structural model.

Second, we examined the predictive capabilities of the structural model. The PLS-SEM's structural model was assessed by the model's predictive capabilities instead of the goodness of fit. The most commonly used criteria to evaluate a structural model's predictive capabilities are $\mathrm{R}^{2}$ and $\mathrm{Q}^{2} . \mathrm{R}^{2}$ measures a model's predictive accuracy, with a higher value indicating a higher level of accuracy. In disciplines such as consumer behavior, $\mathrm{R}^{2}$ values of 0.2 are considered high [85]. $\mathrm{Q}^{2}$ measures a model's predictive relevance and can be obtained by using a blindfolding procedure. $\mathrm{Q}^{2}$ values larger than zero indicate a model's predictive relevance for a particular endogenous latent variable. Table 4 shows that the structural model has good predictive capabilities.

Finally, we assessed the significance of the path coefficients representing the hypothesized relationships. Significance statistics were produced by bootstrapping 5,000 subsamples of the data.

STS antecedents of customer experience. As proposed by H1-H3, technology adoption has a positive effect on relationship orientation $(0.691, t$-value $=26.919, p$-value $<0.001)$, employee-customer interaction $(0.727, t$-value $=26.081$, 
Table 3 Collinearity assessment: VIF values

\begin{tabular}{lllllll}
\hline Result variables/Predictor variables & 1 & 2 & 3 & 4 & 5 & 6 \\
\hline 1 & Technology adoption & 1 & 1 & 1 & 2.485 \\
2 & Relationship orientation & & & & 2.908 \\
3 & Employee-customer interaction & & & & 3.818 \\
4 & Communication effectiveness & & & & 3.759 & \\
5 & Customer experience & & & & & \\
6 & Relationship quality & & & & & \\
\hline
\end{tabular}

Table $4 \mathrm{R}^{2}$ value and $\mathrm{Q}^{2}$ value

\begin{tabular}{lll}
\hline Endogenous latent variables & $\mathrm{R}^{2}$ & $\mathrm{Q}^{2}$ \\
\hline Relationship orientation & 0.478 & 0.398 \\
Employee-customer interaction & 0.528 & 0.416 \\
Communication effectiveness & 0.525 & 0.403 \\
Customer experience & 0.723 & 0.568 \\
Relationship quality & 0.672 & 0.541 \\
\hline
\end{tabular}

distribution of the indirect effect [85]. We employed procedures from [99] and tested a single multiple-mediation model instead of a separate simple mediation model. The results confirm that the impact of technology adoption on the customer experience is fully mediated by relationship orientation, employee-customer interaction and communication effectiveness (Table 5). The indirect effect of technology adoption on the customer experience through relationship orientation, i.e., technology adoption $\rightarrow$ relationship orien-

Table 5 Direct, indirect, and total effects

\begin{tabular}{llll}
\hline Effects & Paths & Coefficients & $t$-value ${ }^{\mathrm{a}}$ \\
\hline Direct effects & Technology adoption $\rightarrow$ customer experience & .009 & $.1728^{\text {n.s }}$ \\
Indirect effects & Technology adoption $\rightarrow$ relationship orientation $\rightarrow$ customer experience & H1*H5=.113 & $3.281^{* * *}$ \\
& Technology adoption $\rightarrow$ employee-customer interaction $\rightarrow$ customer experience & $\mathrm{H} 2 * \mathrm{H} 6=.235$ & $5.217 * * *$ \\
& Technology adoption $\rightarrow$ communication effectiveness $\rightarrow$ customer experience & H3*H7=.303 & $7.794 * * *$ \\
Total indirect effect & - & .651 & $15.236^{* * *}$ \\
Total effect & - & .659 & $21.961 * * *$ \\
\hline
\end{tabular}

$n . s$ nonsignificant

$* * * p<0.01 ; * * p<0.05 ; * p<0.10$

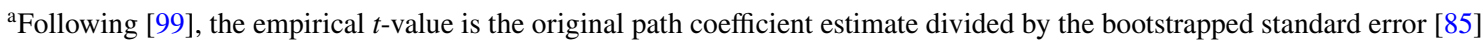

$p$-value $<0.001)$, and communication effectiveness $(0.725$, $t$-value $=27.736, p$-value $<0.001)$. With regard to $\mathrm{H} 4$, Table 5 shows the direct effect of technology adoption on the customer experience, which is nonsignificant $(0.009$, $t$-value $=0.1728, p$-value $=0.8628)$. To better understand this result, we further analyzed the indirect effect of technology adoption on the customer experience in the following mediation test section. With regard to $\mathrm{H} 5-\mathrm{H} 7$, the influences of relationship orientation $(0.163, t$-value $=3.334$, $p$-value $<0.001)$, employee-customer interaction $(0.323$, $t$-value $=5.309, p$-value $<0.001)$, and communication effectiveness $(0.417, t$-value $=8.292, p$-value $<0.001)$ on customer experience are significant.

In testing mediating effects, many scholars have followed the causal steps approach proposed by Baron and Kenny [97]. However, Baron and Kenny's approach to determining mediating effects has been widely challenged in recent years [98]. When testing mediating effects, researchers recommend following [99] and bootstrapping the sampling tation $\rightarrow$ customer experience, is $0.113(0.691 \times 0.163)$, and the associated test statistic is significant $(t$-value $=3.281$, $p$-value $<0.001)(\mathrm{H} 8)$. The indirect effect of technology adoption on the customer experience through employeecustomer interaction, i.e., technology adoption $\rightarrow$ employeecustomer interaction $\rightarrow$ customer experience, is 0.235 $(0.727 \times 0.323)$, and the associated test statistic is also significant $(t$-value $=5.217, p$-value $<0.001)$ (H9). Moreover, the indirect effect of technology adoption on the customer experience through communication effectiveness, i.e., technology adoption $\rightarrow$ communication effectiveness $\rightarrow$ customer experience, is confirmed with a coefficient equal to $0.303(0.725 \times 0.417)(t$-value $=7.794, p$-value $<0.001)$ (H10). The total indirect effect is the sum of the three specific indirect effects, that is, $0.113+0.235+0.303=0.651$ $(t$-value $=15.236, p$-value $<0.001)$. Since the indirect effect is significant, the three mediators absorbed some of the direct effect and the direct effect turned nonsignificant 
Table 6 Results of hypothesis tests

\begin{tabular}{|c|c|c|c|c|}
\hline \multicolumn{2}{|l|}{ Paths } & Coefficient & $t$-statistic & $\begin{array}{l}\text { Hypothesis } \\
\text { supported? }\end{array}$ \\
\hline \multicolumn{5}{|c|}{ STS touchpoints as stimuli of customer experience } \\
\hline H1 & Technology adoption $\rightarrow$ relationship orientation & .691 & $26.919 * * *$ & Yes \\
\hline $\mathrm{H} 2$ & Technology adoption $\rightarrow$ employee-customer interaction & .727 & $26.081 * * *$ & Yes \\
\hline $\mathrm{H} 3$ & Technology adoption $\rightarrow$ communication effectiveness & .725 & $27.736 * * *$ & Yes \\
\hline $\mathrm{H} 4$ & Technology adoption $\rightarrow$ customer experience & 659 & $21.961 * * *$ & Yes \\
\hline H5 & Relationship orientation $\rightarrow$ customer experience & .163 & $3.334 * * *$ & Yes \\
\hline H6 & Employee-customer interaction $\rightarrow$ customer experience & .323 & $5.309 * * *$ & Yes \\
\hline $\mathrm{H} 7$ & Communication effectiveness $\rightarrow$ customer experience & .417 & $8.292 * * *$ & Yes \\
\hline $\mathrm{H} 8$ & Technology adoption $\rightarrow$ relationship orientation $\rightarrow$ customer experience & .113 & $3.281 * * *$ & Yes \\
\hline H9 & Technology adoption $\rightarrow$ employee-customer interaction $\rightarrow$ customer experience & .235 & $5.217 * * *$ & Yes \\
\hline H10 & Technology adoption $\rightarrow$ communication effectiveness $\rightarrow$ customer experience & .303 & $7.794 * * *$ & Yes \\
\hline \multicolumn{5}{|c|}{ Relationship quality as response in customer experience } \\
\hline H11 & Customer experience $\rightarrow$ relationship quality & .820 & $48.243 * * *$ & Yes \\
\hline \multicolumn{5}{|c|}{ CLV as mediator } \\
\hline $\mathrm{H} 12 \mathrm{a}$ & Relationship orientation*CLV $\rightarrow$ customer experience & .040 & $1.971 * *$ & Yes \\
\hline $\mathrm{H} 12 \mathrm{~b}$ & Employee-customer interaction* $\mathrm{CLV} \rightarrow$ customer experience & .033 & $2.027 * *$ & Yes \\
\hline $\mathrm{H} 12 \mathrm{c}$ & Communication effectiveness ${ }^{*} \mathrm{CLV} \rightarrow$ customer experience & .046 & $2.347 * *$ & Yes \\
\hline
\end{tabular}

$n . s$ nonsignificant

$* * * p<0.01 ; * * p<0.05 ; * p<0.10$

$(0.009, t$-value $=0.1728, p$-value $=0.8628)$. The total effect of technology on customer experience is 0.659 , which is statistically significant $(t$-value $=21.961, p$-value $<0.001)$; thus, H4 is supported. The size of the indirect effect in relation to the total effect (VAF, variance accounted for) equals $98.8 \%(0.651 / 0.659)$. A large VAF of above $80 \%$ indicates that relationship orientation, employee-customer interaction, and communication effectiveness fully mediate the effect of technology adoption on the customer experience.

Consequences of customer experience After testing the STS antecedents of the customer experience, we investigated relationship quality as a consequence of the customer experience. The coefficient for this relationship is positive and significant $(0.820, t$-value $=48.243, p$-value $<0.001)$, providing evidence for $\mathrm{H} 11$.

Moderators of customer experience We tested the moderation effects of CLV. H12a-c proposed a positive moderation effect of CLV on the relationship between the customer experience and (a) relationship orientation, (b) employeecustomer interaction, and (c) communication effectiveness. As Table 6 shows, all three interaction terms-relationship orientation*CLV $(0.040, t$-value $=1.971, p<0.05)$, employee-customer interaction $* \operatorname{CLV}(0.033, t$-value $=2.027$, $p<0.05)$, and communication effectiveness* CLV (0.046, $t$-value $=2.347, p<0.05)$ - have significant positive effects on the customer experience. Path coefficients, $t$-values, $p$-values and the results of hypotheses tests are presented in Fig. 4 and Table 6.

\section{Discussion and implications}

Our goal in this study was to understand the customer experience in a new technological environment. Although the customer experience has drawn both academics' and practitioners' attention, much more research needs to be conducted to further understand the determinants, consequences, and moderators of the customer experience, especially in today's technology landscape. Drawing on the SOR framework [16] and STS theory [48], we built our research on the WeChat m-payment-based smart retail system and attempted to develop an integrated model of the smart retail customer experience. In addition, the present research provides empirical evidence for the moderating effect of CLV as a customer trading characteristic.

\subsection{Theoretical implications}

Our study has several theoretical implications. First, our study built an integrated customer experience framework based on SOR theory and empirically tested the determinants, consequences, and moderators of the customer experience. Previously, researchers have suggested that the SOR model can work as the theoretical basis for customer experience research. However, except for limited empirical studies such as Kumar et al. customer experience study in the healthcare sector [43], prior studies exploring the customer experience on an SOR basis were mainly qualitative 
STS touchpoint as environment stimuli (S)

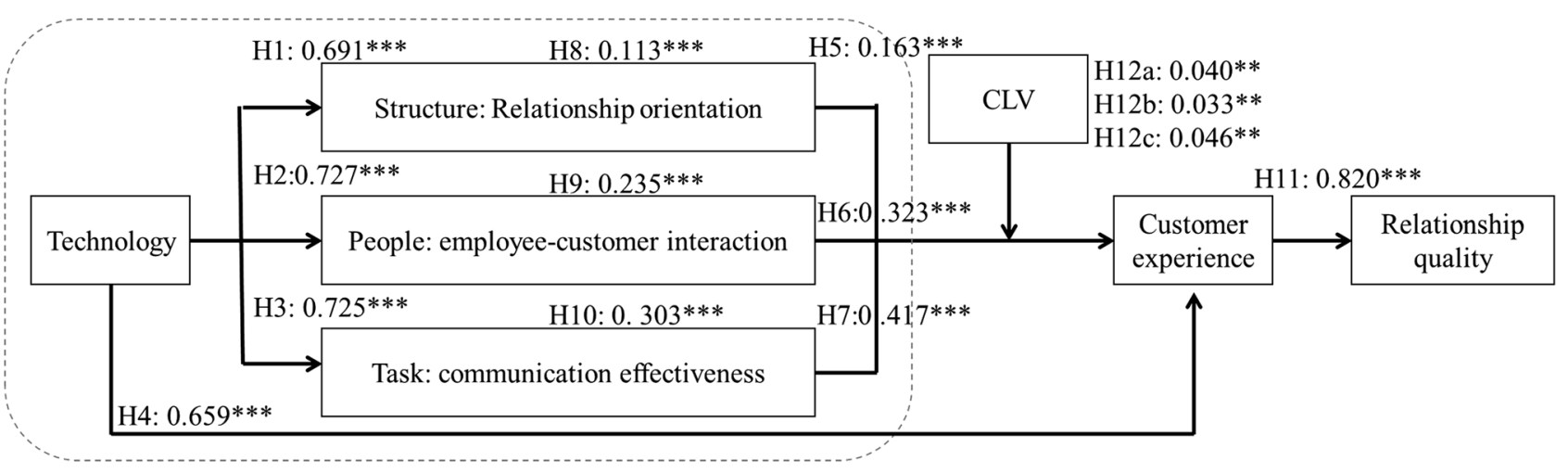

Fig. 4 Structural model: path coefficients and significance levels. (***p ${ }^{*} 0.01 ; * * p<0.05 ; * p<0.10 ; n . s$ nonsignificant)

or conceptual $[42,100]$. Our study may provide empirical support for SOR as a solid theoretical foundation for retail customer experience research. In addition, our SOR-based research supports the understanding of the retail customer experience from a holistic perspective.

Second, our study contributes to the existing literature on the determinants of the retail customer experience. Customer experience determinants emerge during the customer journey through customer interaction with a large number of touchpoints. Previous studies have explored touchpoints such as store atmosphere [101], product assortment [46] and salespersons [102]. Instead of adopting a store attributes perspective, our study was based on STS theory and treated a retailer as an STS with four interacting components, i.e., technology, structure, people, and tasks. Since smart technology has brought significant changes to the retail field, we specifically emphasized the role technology plays in the system. We analyzed how the WeChat m-payment-based smart retail system can empower a retailer with new capabilities to optimize its management and structure, enhance employee competence, and better complete tasks, in turn improving its customer-perceived relationship orientation, employeecustomer interaction, and communication effectiveness. Our empirical results demonstrated that customers' interaction with these social-technical touchpoints influences their retail experience. More specifically, technology can enhance the customer experience by improving customer-perceived relationship orientation, employee-customer interaction, and communication effectiveness.

Third, we tested the moderating effect of customer trading characteristics, i.e., CLV. Prior studies have explored the moderating effects of customer sociodemographic characteristics, such as age, gender, or income, or psychographic factors, such as mood, attitude, or shopping motives, on the customer experience $[10,11]$. In the current study, we focused on the moderating role of customer trading characteristics. The empirical results showed that the effects of relationship orientation, employee-customer interaction, and communication effectiveness on the customer experience are stronger when CLV increases. Our study demonstrated that CLV plays an important role in the customer experience framework. An increase in CLV helps enhance the effect of STS stimuli on the retail customer experience. By testing the moderating effects of CLV, we synthesized the central idea of the customer relationship management field into the CEM research. We add knowledge to the moderators of the customer experience.

Fourth, our study contributes to the research method of integrating and matching customer transaction data with survey data. Transaction data reflect customers' actual purchase behavior, whereas survey data reflect customers' attitudes and perceptions, which help explain the motives underlying customer behavior. The integration of transaction data and survey data could provide new insight in customer research. However, data fusion research is still in its infancy, and there is still much to learn about the processes and benefits of integrating transaction data and survey data [103]. Our study provided a preliminary application of an integrated dataset and empirically tested the conceptual model of the customer experience.

\subsection{Managerial implications}

Our study demonstrated that the customer experience is an important driver of relationship quality, which means that delivering a superior customer experience could result in more customer trust and higher customer satisfaction. Therefore, retail managers should realize the importance of this emerging idea and develop CEM initiatives. Our study makes the following recommendations:

Retailers should develop their capabilities to improve their communication effectiveness, optimize their relationship-oriented management, and enhance their employee competence to build better interaction with customers. 
Retailers must understand the customer journey and recognize customer touchpoints that could create a superior customer experience. Our study demonstrated that relationship orientation, employee-customer interaction, and communication effectiveness are essential touchpoints for the retail customer experience. Among them, communication effectiveness has the most significant influence on the customer experience (standardized coefficient $=0.417$ ), followed by employee-customer interaction (standardized coefficient $=0.323$ ) and then relationship orientation (standardized coefficient $=0.163$ ).

Retailers should take advantage of smart technology to empower their organization. Although technology plays a vital role in improving the customer experience, our study showed that this effect is not direct but achieved through an organization's management, people, and tasks. Therefore, retailers should increase their ability to keep up with and make full use of smart technologies, such as the WeChat $\mathrm{m}$-payment system, to reshape their management and structure, enhance employee competence, and improve task fulfillment efficiency. By doing so, retailers can optimize the data collection process, enhance data analysis quality, identify market trends and customer needs, and provide more interactive and personalized services.

Retailers should pay more attention to CLV. CLV is considered an important criterion for customer selection and resource allocation [104]. Our study demonstrated that marketing stimuli (touchpoints) influence the customer experience when CLV increases. Therefore, CLV plays an important role in CEM. Retailers should make every effort to improve CLV.

\section{Limitations and future research}

Our study has several limitations, and these limitations point to directions for future research. We tested the moderating effects of CLV. This variable was calculated based on customers' actual transaction data, which could measure the variable more objectively and accurately than their survey data. However, only transactions on WeChat Pay were used in the calculation of CLV. In future research, transactions on Alipay, another major m-payment service provider, could be merged with transactions on WeChat to obtain a complete picture of customers' shopping behavior. This study's calculation of CLV was based on classical probability models, i.e., Pareto/GGG and gamma-gamma distributions. In future research, machine learning methods such as random forest, support vector machine, and gradient-boosted decision trees can be utilized to measure CLV with massive customer data. These methods usually have good predictive performance. The classical probability models and the modern machine learning method can also be combined to predict CLV.

\section{Appendix 1}

Scale items, loadings and reliabilities.

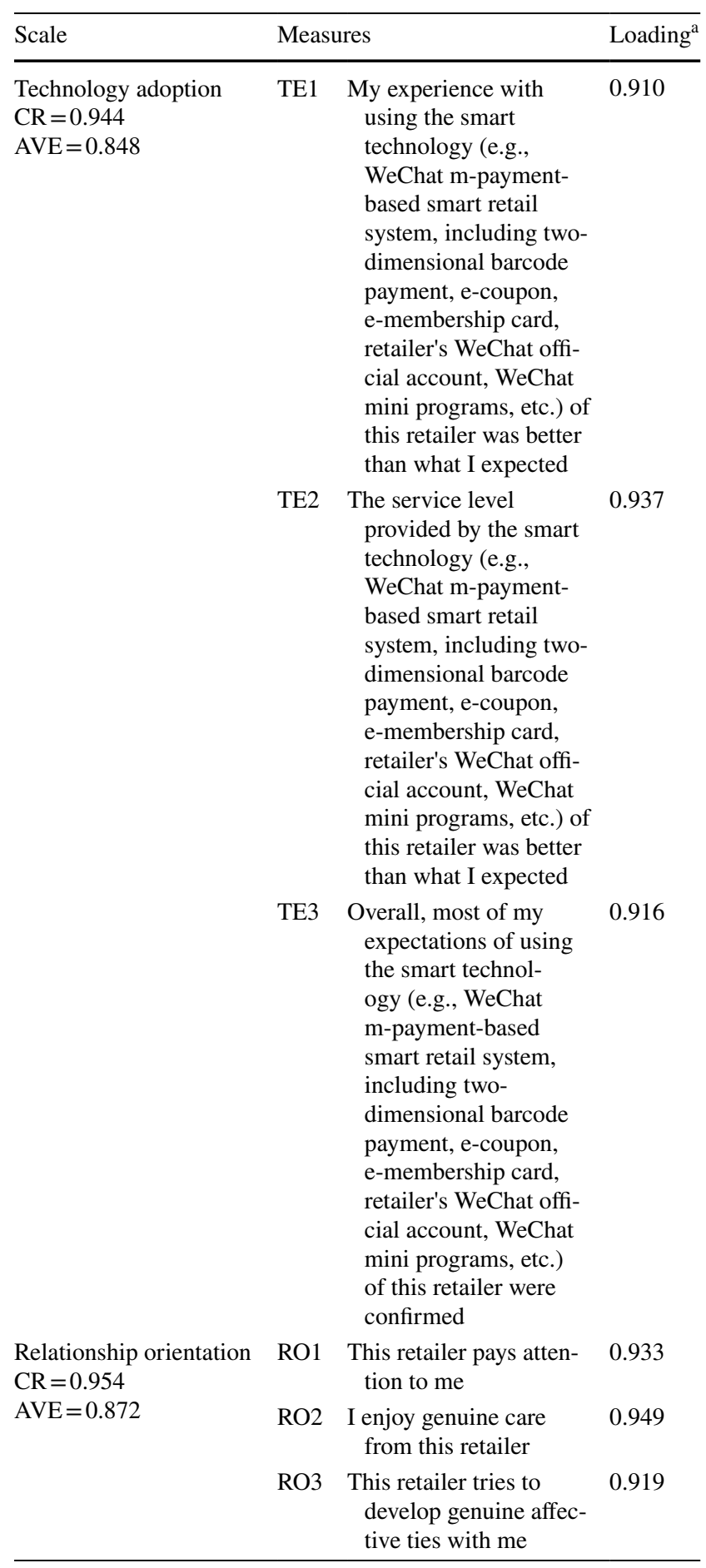




\begin{tabular}{|c|c|c|c|}
\hline \multirow{2}{*}{$\begin{array}{l}\text { Scale } \\
\text { Employee-customer } \\
\text { interaction } \\
\mathrm{CR}=0.951 \\
\mathrm{AVE}=0.83\end{array}$} & \multicolumn{2}{|c|}{ Measures } & \multirow{2}{*}{$\frac{\text { Loading }^{\mathrm{a}}}{0.893}$} \\
\hline & ECI1 & $\begin{array}{l}\text { The staff members of } \\
\text { this retailer give me } \\
\text { personal attention }\end{array}$ & \\
\hline $\mathrm{AVE}=0.83$ & ECI2 & $\begin{array}{l}\text { The staff members of } \\
\text { this retailer are always } \\
\text { willing to help me }\end{array}$ & 0.930 \\
\hline & ECI3 & $\begin{array}{l}\text { The staff members of } \\
\text { this retailer provide me } \\
\text { with prompt service }\end{array}$ & 0.929 \\
\hline & ECI4 & $\begin{array}{l}\text { The staff members of } \\
\text { this retailer are courte- } \\
\text { ous }\end{array}$ & 0.890 \\
\hline \multirow[t]{3}{*}{$\begin{array}{l}\text { Communication effec- } \\
\text { tiveness } \\
\mathrm{CR}=0.923 \\
\mathrm{AVE}=0.800\end{array}$} & CE1 & $\begin{array}{l}\text { The retailer can provide } \\
\text { me with an easy and } \\
\text { meaningful introduc- } \\
\text { tion to the products I } \\
\text { am interested in }\end{array}$ & 0.905 \\
\hline & CE2 & $\begin{array}{l}\text { The retailer provides me } \\
\text { with relevant promo- } \\
\text { tion information in a } \\
\text { timely manner }\end{array}$ & 0.878 \\
\hline & CE3 & $\begin{array}{l}\text { The retailer provides } \\
\text { me with professional } \\
\text { advice when I'm not } \\
\text { sure which is the best } \\
\text { product to choose }\end{array}$ & 0.899 \\
\hline \multirow{6}{*}{$\begin{array}{l}\text { Customer experience } \\
\mathrm{CR}=0.967 \\
\mathrm{AVE}=0.828\end{array}$} & CX1 & $\begin{array}{l}\text { When shopping at this } \\
\text { retailer, I feel excited }\end{array}$ & 0.879 \\
\hline & CX2 & $\begin{array}{l}\text { When shopping at this } \\
\text { retailer, I feel engaged }\end{array}$ & 0.906 \\
\hline & CX3 & $\begin{array}{l}\text { When shopping at } \\
\text { this retailer, I feel } \\
\text { refreshed }\end{array}$ & 0.912 \\
\hline & CX4 & $\begin{array}{l}\text { My shopping experi- } \\
\text { ence at this retailer is } \\
\text { unique }\end{array}$ & 0.914 \\
\hline & CX5 & $\begin{array}{l}\text { My shopping experi- } \\
\text { ence at this retailer is } \\
\text { memorable }\end{array}$ & 0.919 \\
\hline & CX6 & $\begin{array}{l}\text { My shopping experi- } \\
\text { ence at this retailer is } \\
\text { wonderful }\end{array}$ & 0.929 \\
\hline \multirow{4}{*}{$\begin{array}{l}\text { Relationship quality } \\
\mathrm{CR}=0.956 \\
\mathrm{AVE}=0.846\end{array}$} & RQ1 & $\begin{array}{l}\text { This retailer is really } \\
\text { trustworthy }\end{array}$ & 0.920 \\
\hline & RQ2 & $\begin{array}{l}\text { This retailer is very } \\
\text { competent in its field }\end{array}$ & 0.946 \\
\hline & RQ3 & $\begin{array}{l}\text { This retailer keeps its } \\
\text { promises and commit- } \\
\text { ments }\end{array}$ & 0.923 \\
\hline & RQ4 & $\begin{array}{l}\text { Generally, I am very } \\
\text { satisfied with my } \\
\text { relationship with this } \\
\text { retailer }\end{array}$ & 0.888 \\
\hline
\end{tabular}

$C R$ composite reliability, $A V E$ average variance extracted.

${ }^{\text {a } A l l ~ l o a d i n g s ~ s i g n i f i c a n t ~ a t ~} p<0.001$.

\section{Appendix 2}

CLV for twenty customers.

\begin{tabular}{lccl}
\hline Customer ID & $\widehat{F}$ (Frequency) & $\hat{M}$ (RMB) & CLV (RMB) \\
\hline 1 & 22.83 & 30.45 & 695 \\
2 & 125.37 & 29.35 & 3679 \\
3 & 23.12 & 30.19 & 698 \\
4 & 140.66 & 88.67 & 12,473 \\
5 & 112.2 & 85.82 & 9629 \\
6 & 51.61 & 62.12 & 3206 \\
7 & 72.92 & 39.12 & 2853 \\
8 & 32.2 & 91.57 & 2949 \\
9 & 11.87 & 78.60 & 933 \\
10 & 15.03 & 98.90 & 1486 \\
11 & 22.9 & 57.30 & 1312 \\
12 & 13.29 & 54.70 & 727 \\
13 & 74.06 & 61.01 & 4518 \\
14 & 100.84 & 34.23 & 3452 \\
15 & 44.49 & 54.67 & 2432 \\
16 & 63.83 & 29.48 & 1882 \\
17 & 21.85 & 70.32 & 1537 \\
18 & 30.02 & 103.96 & 3121 \\
19 & 61.14 & 46.72 & 2857 \\
20 & 33.58 & 59.58 & 2001 \\
\hline
\end{tabular}

Acknowledgements We would like to sincerely thank Dr. Dehong Yang from Miya Information Technology, Inc., for his support.

Funding This study is supported by the fund for building world-class universities (disciplines) of Renmin University of China and by the Byron Root Foundation, USA.

Availability of data and material The datasets used or analyzed in the current study are available from the corresponding author upon reasonable request.

\section{Declarations}

Conflict of interest The authors declare that they have no conflicts of interest related to this work.

Open Access This article is licensed under a Creative Commons Attribution 4.0 International License, which permits use, sharing, adaptation, distribution and reproduction in any medium or format, as long as you give appropriate credit to the original author(s) and the source, provide a link to the Creative Commons licence, and indicate if changes were made. The images or other third party material in this article are included in the article's Creative Commons licence, unless indicated otherwise in a credit line to the material. If material is not included in the article's Creative Commons licence and your intended use is not permitted by statutory regulation or exceeds the permitted use, you will need to obtain permission directly from the copyright holder. To view a copy of this licence, visit http://creativecommons.org/licenses/by/4.0/. 


\section{References}

1. Crandell C (2013) Customer experience: is it the chicken or the egg? Forbes. https://www.forbes.com/sites/christinecrande 11/2013/01/21/customer-experience-is-it-the-chicken-or-egg/

2. Smilansky O (2017) 7 myths of customer experience (and why they are wrong). Customer relationship management 28-32

3. Lemon KN, Verhoef PC (2016) Understanding customer experience throughout the customer journey. J Mark: AMA/MSI Special Issue 80:69-96

4. Holbrook MB, Hirschman EC (1982) The experiential aspects of consumption: Consumer fantasies, feelings, and fun. J Consum Res 9(2):132-140

5. Schmitt BH (1999) Experiential marketing: how to get customer to sense, feel, think, act and relate to your company and brands. The Free Press, New York

6. Klaus P, Maklan S (2013) Towards a better measure of customer experience. Int J Mark Res 55(2):227-246

7. Terblanche NS (2018) Revisiting the supermarket in-store customer shopping experience. J Retail Consum Serv 40:48-59

8. Verhoef PC, Lemon KN, Parasuraman A, Roggeveen A, Tsiros M, Schlesinger LA (2009) Customer experience creation: determinants, dynamics, and management strategies. J Retail 85(1):31-41

9. Grewal D, Levy M, Kumar V (2009) Customer experience management in retailing: an organizing framework. J Retail $85: 1-14$

10. Jain R, Aagja J, Bagdare S (2017) Customer experience-a review and research agenda. J Serv Theory Pract 27(3):642-662

11. Esbjerg L, Jensen BB, Bech-Larsen T, De Barcellos MD, Boztug Y, Grunert KG (2012) An integrative conceptual framework for analyzing customer satisfaction with shopping trip experiences in grocery retailing. J Retail Consum Serv 19:445-456

12. Pantano E, Timmermans $H$ (2014) What is smart for retailing? Procedia Environ Sci 22:101-107

13. Adapa S, Fazal-e-Hasan SM, Makam SB, Azeem MM, Mortimer G (2020) Examining the antecedents and consequences of perceived shopping value through smart retail technology. J Retail Consum Serv 52:1-11

14. Research and Markets (2015) Retail IoT market growth \& forecast 2015 to 2020 . Accessed from http://www.marketsandmarke tsblog.com/retail-iot-market.html

15. Flavián C, Ibáñze-Sánchez S, Orús C (2019) The impact of virtual, augmented and mixed reality technologies on the customer experience. J Bus Res 100:547-560

16. Thomas A (2017) Multivariate hybrid pathways for creating exceptional customer experiences. Bus Process Manag J 23(4):822-829

17. Parise S, Guinan PJ, Kafka R (2016) Solving the crisis of immediacy: how digital technology can transform the customer experience. Bus Horiz 59:411-420

18. Rodríguez M, Paredes F, Yi G (2016) Towards future customer experience: trends and innovation in retail. Foresight and STI governance 10(3): 18-28

19. Silva JHO, Mendes GHS, Miguel PAC, Amorim M, Teixeira JG (2021) Customer experience research: intellectual structure and future research opportunities. J Serv Theory Pract. https://doi. org/10.1108/JSTP-08-2020-0193

20. Zhang M, Hu M, Guo L, Liu W (2017) Understanding relationships among customer experience, engagement, and word-ofmouth intention on online brand communities: the perspective of service ecosystem. Internet Res 27(4):839-857
21. Kang YJ, Lee WJ (2018) Effects of sense of control and social presence on customer experience and e-service quality. Inf Dev 34(3):242-260

22. McLean G, Al-Nabhani K, Wilson A (2018) Developing a mobile applications customer experience model (MACE) - implication for retailers. J Bus Res 85:325-336

23. Chylinski M, Heller J, Hilken T, Keeling DI, De Ruyter K, Mahr D (2020) Augmented reality marketing: a technology-enabled approach to situated customer experience. Australas Mark J 28(4):374-384

24. Dacko SG (2017) Enabling smart retail settings via mobile augmented reality shopping apps. Technol Forecast Soc Chang 124(11):243-256

25. Dieck MCT, Han DD (2021) The role of immersive technology in customer experience management. J Mark Theory Pract. https://doi.org/10.1080/10696679.2021.1891939

26. Hoyer WD, Kroschke M, Schmitt B, Kraume K, Shankar V (2020) Transforming the customer experience through new technologies. J Interact Mark 51:57-71

27. Taylor E (2016) Mobile payment technologies in retail: a review of potential benefits and risks. Int J Retail Distrib Manag 44(2):159-177

28. Raina VK (2014) Overview of mobile payment: technologies and security. In: Liebana F, Munoz-Leiva F, and SanchezFernandez J (eds) Electronic payment system for competitive advantage in E-commerce. IGI Global

29. Gerpott T, Kornmeier K (2009) Determinants of customer acceptance of mobile payment systems. Int J Electron Finance $3(1): 1-30$

30. Liébana-Cabanillas F, Sánchez-Fernández J, Muñoz-Leiva F (2014) Antecedents of the adoption of the new mobile payment systems: the moderating effect of age. Comput Hum Behav $35: 464-478$

31. Zhou T (2013) Understanding usage of mobile sites. Ind Manage Data Syst 113(9):1289-1299

32. Ondrus J, Pigneur Y (2009) Near field communication: an assessment for future payment systems. IseB 7(3):347-361

33. Cox C, Sanchez S (2012) Transforming the customer experience: The promise of mobile wallets. First Data Corporation

34. Varshneya G, Das G, Khare A (2017) Experiential value: a review and future research directions. Mark Intell Plan 35(3):339-357

35. Le ANH, Nguyen-Le XD (2020) A moderated mediating mechanism of omnichannel customer experiences. Int J Retail Distrib Manag. https://doi.org/10.1108/IJRDM-02-2020-0054

36. Reinartz WJ, Kumar V (2003) The impact of customer relationship characteristics on profitable lifetime duration. J Mark 67(1):77-99

37. Zeithaml VA, Rust RT, Lemon KN (2001) The customer pyramid: creating and serving profitable customer. Calif Manage Rev 42(4):118-142

38. Venkatesan R, Kumar V (2004) A customer lifetime value framework for customer selection and resource allocation. J Mark 68(4):106-125

39. Mehrabian A, Russell JA (1974) An approach to environmental psychology. MIT press, Cambridge

40. Donovan RJ, Rossiter JR (1982) Store atmosphere: an environmental psychology approach. J Retail 58(1):283-294

41. Lucia-Palacios L, Pérez-López R, Polo-Redondo Y (2016) Cognitive, affective and behavioural responses in mall experience: A qualitative approach. Int J Retail Distrib Manag 44(1):4-21

42. Mollen A, Wilson H (2010) Engagement, telepresence and interactivity in online consumer experience: reconciling scholastic and managerial perspective. J Bus Res 63:919-925 
43. Kumar RS, Dash S, Malhotra NK (2018) The impact of marketing activities on service brand equity: the mediating role of evoked experience. Eur J Mark 52(3/4):596-618

44. Zhang H, Lu Y, Gupta S, Zhao L (2014) What motivates customers to participate in social commerce? The impact of technological environments and virtual customer experience. Inf Manag 51:1017-1030

45. Fan X, Ning N, Deng N (2020) The impact of the quality of intelligent experience on smart retail engagement. Mark Intell Plan 38(7):877-891

46. Hart C, Stachow G, Cadogan JW (2013) Conceptualising town center and the customer experience. J Mark Manag 29:15-16

47. Waqas M, Hamzah ZLB, Salleh NAM (2020) Customer experience: a systematic literature review and consumer culture theorybased conceptualization. Manage Rev Q 71:135-176

48. Trist EL (1981) The evolution of socio-technical systems: A conceptual framework and an action research program. Ontario Quality of Working Life Center, Occasional Paper No. 2

49. Bostrom RP, Heinen JS (1977) MIS problems and failures: a socio-technical perspective, part one: the causes. MIS Quarterly $17-32$

50. Leavitt HJ (1965) Applied organizational change in industry: structural, technological, and humanistic approach. In: March JG (ed) Handbook of organizations. Rand McNally, New York, pp 1144-1170

51. Camarero C (2007) Relationship orientation or service quality? What is the trigger of performance in financial and insurance services? Int J Bank Mark 25(6):406-426

52. Berry LL, Gresham LG (1986) Relationship retailing: transforming customers into clients. Bus Horiz 29(6):43-47

53. Gummesson E (1994) Making relationship marketing operational. Int J Serv Ind Manag 5(5):5-20

54. Grönroos C (1994) From marketing mix to relationship marketing: towards a paradigm shift in marketing. Manag Decis 32(2):4-20

55. Sheth JN, Parvatiyar A (1995) The evolution of relationship marketing. Int Bus Rev 4(4):397-418

56. Larivière B, Bowen D, Andreassen TW, Kunz W, Sirianni NJ, Voss C, Wünderlich NV, De Keyser A (2017) "Service encounter 2.0": an investigation into the role of technology, employees and customers. J Bus Res 79(10): 238-246

57. Surprenant CF, Solomon M (1987) Predictability and personalization in the service encounte. J Mark 51(2):86-96

58. Kitchen PJ, Schultz DE (1999) A multi-country comparison of the driver for IMC. J Advert Res 39(1):21-38

59. Foroudi P, Jin Z, Gupta S, Melewar TC, Foroudi MM (2016) Influence of innovation capability and customer experience on reputation and loyalty. J Bus Res 69:4882-4889

60. Pressey AD, Mathews BP (2000) Barriers to relationship marketing in consumer retailing. J Ser Mark 14(3):272-286

61. Gulati R, Oldroyd JB (2005) The quest for customer focus. Harv Bus Rev 83(4):92-101

62. Stein A, Ramaseshan B (2016) Towards the identification of customer experience touch point elements. J Retail Consum Serv 30:8-19

63. Kim H, Choi B (2013) The influence of customer experience quality on customers' behavioral intentions. Serv Mark Q 34:322-338

64. Srivastava M, Kaul D (2014) Social interaction, convenience and customer satisfaction: The mediating effect of customer experience. J Retail Consum Serv 21:1028-1037

65. McLean G, Osei-Frimpong K (2017) Examining satisfaction with the experience during alive chat service encounter-implications for website providers. Comput Hum Behav 76(11):494-508
66. Brakus JJ, Schmitt BH, Zarantonello L (2009) Brand experience: What is it? How is it measured? Does it affect loyalty? J Mark 73(3):52-68

67. Pantano E, Priporas CV, Dennis C (2018) A new approach to retailing for successful competition in the new smart scenario. Int J Retial Distrib Manag 46(3):264-282

68. Mosquera A, Pascual CR, Ayensa EJ (2017) Understanding the customer experience in the age of omni-channel shopping. Icono 14 15(2):166-185

69. Mulhern F (2009) Integrated marketing communications: From media channels to digital connectivity. J Mark Commun 15(2-3):85-101

70. Mohd-Ramly S, Omar NA (2017) Exploring the influence of store attributes on customer experience and customer engagement. Int J Retail Distrib Manag 45(11):1138-1158

71. Rose S, Hair N, Clark M (2011) Online customer experience: a review of the business-to-consumer online purchase context. Int J Manag Rev 13:24-39

72. Henning-Thuran T, Klee A (1997) The impact of customer satisfaction and relationship quality on customer retention: a critical reassessment and model development. Psychol Mark 14(8):737-764

73. Crosby LA, Evans KR, Cowles D (1990) Relationship quality in services selling: an interpersonal influence perspective. J Mark 54:68-81

74. Moorman C, Zaltman G, Deshpande R (1992) Relationships between providers and users of market research: the dynamics of trust within and between organizations. J Mark Res 29(3):314-328

75. Jin N, Line ND, Goh B (2013) Experiential value, relationship quality, and customer loyalty in full-service restaurants: the moderating role of gender. J Hosp Market Manag 22(7):679-700

76. Bilgihan A, Nusair K, Okumus F, Cobanoglu C (2015) Applying flow theory to booking experiences: an integrated model in an online service context. Inf Manage 52:668-678

77. Rajaobelina L (2018) The impact of customer experience on relationship quality with travel agencies in a multichannel environment. J Travel Res 57(2):206-217

78. O'Neill M, Palmer A (2004) Cognitive dissonance and the stability of service quality perceptions. J Serv Mark 18(6):433-449

79. Bogomolova S (2011) Service quality perceptions of solely loyal customers. Int J Mark Res 53(6):793-810

80. Bandyopadhyay S, Gupta K, Dube L (2005) Does brand loyalty influence double jeopardy? A theoretical and empirical study. J Prod Brand Manag 14(7):414-423

81. Mittal V, Katrichis JM (2000) Distinctions between new and loyal customers. Mark Res 12(1):26-32

82. Ganesh J, Arnold MJ, Reynolds KE (2000) Understanding the customer base of service providers: an examination of the differences between switchers and stayers. J Mark 64(3):65-87

83. Bird M, Channon C, Ehrenberg ASC (1970) Brand image and brand usage. J Mark Res 7(3):307-314

84. Segal MN (1989) Implications of single vs multiple buying sources. Ind Mark Manage 18(3):163-178

85. Hair JF, Hult GTM, Ringle CM, Sarstedt M (2014) A primer on partial least squares structural equation modeling (PLS-SEM). Sage Publications, California

86. Bhattacherjee A (2001) Understanding information systems continuance: An expectation-confirmation model. MIS Q 25(3):351-370

87. Aurier P, Séré de Lanauze G (2012) Impacts of perceived brand relationship orientation on attitudinal loyalty: An application to strong brands in the packaged goods sector. Eur J Mark 46(11):1602-1627 
88. Sharma N, Patterson PG (1999) The impact of communication effectiveness and service quality on relationship commitment in consumer, professional services. J Serv Mark 13(2):151-170

89. Bagdare S, Jain R (2013) Measuring retail customer experience. Int J Retail Distrib Manag 41(10):790-804

90. Jain D, Singh SS (2002) Customer lifetime value research in marketing: A review and future directions. J Interact Mark 16(2):34-36

91. Kumar V, Reinartz W (2016) Creating enduring customer value. J Mark 80(5):36-68

92. Platzer M, Reutterer T (2016) Ticking away the moments: timing regularity helps to better predict customer activity. Mark Sci 35(5):693-829

93. Colombo R, Jiang W (1999) A stochastic RFM model. J Interact Mark 13(3):2-12

94. Fader PS, Hardie BGS, Lee KL (2005) RFM and CLV: using iso-value curves for customer base analysis. J Mark Res 42(4):415-430

95. Barclay DW, Higgins CA, Thompson R (1995) The partial least squares approach to causal modeling: personal computer adoption and use as illustration. Technol Stud 2:285-309

96. Fornell C, Larcker DF (1981) Evaluating structural equation models with unobservable variables and measurement errors. J Mark Res 18:39-50

97. Baron RM, Kenny DA (1986) The moderator-mediator variable distinction in social psychological research: conceptual, strategic and statistical considerations. J Pers Soc Psychol 51(6):1173-1182

98. Nitzl C, Roldan JL, Cepeda G (2016) Mediation analysis in partial least squares path modeling: helping researchers discuss more sophisticated model. Ind Manage Data Syst 116(9):1849-1864
99. Preacher KJ, Hayes AF (2008) Asymptotic and resampling strategies for assessing and comparing indirect effects in multiple mediator models. Behav Res Methods 40(3):879-891

100. Hwangbo H, Kim YS, Cha KJ (2017) Use of the smart store for persuasive marketing and immersive customer experiences: a case study of Korean apparel enterprise. Hindawi Mobile Information System 1-17

101. Spence C, Puccinelli NM, Grewal D, Roggeveen AL (2014) Store atmospherics: A multisensory perspective. Psychol Mark 31(7):472-488

102. Lee S, Lim T (2017) Retailer's innovative differentiation method based on customer experience: focusing mediating effect of omni-channel shopper type. Qual Innov Prosper 21(2):37-51

103. Gupta S, Hanssens D, Hardie B, Kahn W, Kumar V, Lin N, Ravishanker N, Sriram S (2006) Modeling customer lifetime value. J Serv Res 9(2):139-155

104. Kumar V (2008) Managing Customers for Profit: Strategies to Increase Profits and Build Loyalty. Wharton School Publishing, Upper Saddle River

105. Smith J, Anderson S, Fox G (2017) A quality system's impact on the service experience. Int J Oper Prod Manag 37(12):1817-1839

Publisher's Note Springer Nature remains neutral with regard to jurisdictional claims in published maps and institutional affiliations. 